\title{
12
}

\section{PORTFOLIO CHALLENGES}

\section{Mount Lyell's survival in question}

Charles Copeman, a senior executive of Consolidated Gold Fields Australia (CGFA), was appointed chairman of Mount Lyell Mining and Railway Company in late 1976. With his responsibilities as chairman of Bellambi Coal, this was one of two demanding directorships he held while an executive director of CGFA. Despite being asked by the London directors to close Mount Lyell, he instead oversaw the continuation of the operation although at a much reduced scale and with an approach to both the Tasmanian and Commonwealth governments for financial assistance. ${ }^{1}$ The continuation or otherwise of Mount Lyell was an important economic and social issue for Tasmania. In terms of seeking governmental financial support, CGFA and the board of Mount Lyell were aided by the fact that voting intentions in Tasmania were crucial in Commonwealth electoral outcomes for both of the two major political parties. As such, the continuation of mining operations at Mount Lyell gained a high level of bipartisan support. ${ }^{2}$

\footnotetext{
1 Charles Copeman, interview by John Farquarson, National Library of Australia, session 2.

2 Copeman recorded that the Tasmanian premier asked the Liberal Party opposition leader, Max Bingham, into his office, and that Bingham phoned the prime minister, Malcolm Fraser. Fraser was concerned at the electoral consequences of the potential closure of Mount Lyell. Subsequently, payroll tax exemptions were granted by the Tasmanian Government, while Commonwealth subsidies were also forthcoming. Copeman also recorded that when Fraser met the CGFA managing director and chairman, Massy-Greene, he inquired how much the Australian dollar needed to decline in value to keep Mount Lyell operating (Charles Copeman, interview by John Farquarson, National Library of Australia, session 2).
} 
The report of the Senate Select Committee that investigated the impact of the potential closure of Mount Lyell on the regional economy was followed in 1977 by an Industries Assistance Commission inquiry into whether financial support should be provided to Australian copper producers, most notably Mount Lyell. ${ }^{3}$ In briefing notes Copeman prepared for his engagement with the Industries Assistance Commission, it was detailed that since CGFA had acquired its 56 per cent interest in Mount Lyell in 1964 for $\$ 11.9$ million, there had been capital expenditure of $\$ 61$ million, with CGFA receiving $\$ 10.1$ million in dividends of which $\$ 3.1$ million came from Mount Lyell companies other than mining. As such, the original investment in Mount Lyell, based on the then current share price, had delivered a real rate of return of 0.24 per cent. $^{4}$

It was made clear that closure was likely if governmental assistance was not forthcoming. While not a part of the assistance sought, CGFA also conveyed that its North-West Acid joint venture operation with EZ Industries was also in a parlous financial state.

The Industries Assistance Commission examined the serious repercussions for the township of Queenstown and the regional area if the Mount Lyell operation were to close. Its interim report concluded:

The community of Queenstown is almost entirely dependent on the Mount Lyell mine and existing adjustment measures appear inadequate to deal with the scale of economic and social stress which would occur there if the mine were to close ... The immediate effect of the closing of the mine would be to increase substantially the level of unemployment in Queenstown and Gormanston. ${ }^{5}$

The financial circumstances of Mount Lyell relative to the more favourable operating conditions of Renison highlighted the deficiencies of the CGFA group structure, something that had been under active consideration since 1975. As Copeman conveyed at the inquiry:

3 The Senate Select Committee recommended governmental financial assistance for Mount Lyell, given the adverse effects on unemployment in an area with few alternative employment opportunities (Australian Senate, 'Report of Senate Select Committee for Mount Lyell Mining Operations', 3 December 1976, Renison Goldfields Consolidated Archives (RGCA), Box 746).

4 Part of notes prepared for Industries Assistance Commission and request by Mt Lyell for assistance, RGCA, Box 746.

5 'Report of Senate Select Committee for Mount Lyell Mining Operations', 3 December 1976, Renison Goldfields Consolidated Archives (RGCA), Box 746). 
The Goldfields group, as I think you understand, is a group of strange structure ... Renison and Lyell are owned roughly 35\% to $40 \%$ foreign and the rest is owned by Australians ... It puts the group into a situation where it does not just direct that there is a surplus cash in one company and say it should go into this company because that other company is short ... [consequently] the rather poor financial position the company has got into [is] largely as a result of the Mount Lyell problem and one or two other problems in the group. ${ }^{6}$

\section{Copeman went on to state:}

I think these are very sobering occasions for all of us when we are dealing with matters of very great personal significance to people who live in this community. I think it is not something any of us are trained for or that any of us have particularly clever answers to, except to say we have spent three years trying to come up with, and in those three years we have come up with, a lot of better answers. We have run out of answers now, and that is why as an ultimate step we have asked for this inquiry. ${ }^{7}$

In 1977, Mount Lyell sought temporary financial assistance from the Commonwealth Government to offset losses and forestall what the company conveyed would otherwise be the necessity to close the operation. In 1978 , this became a request for an interest-free loan of $\$ 632,000$ with a company statement made that if this assistance was not forthcoming it would be viewed 'as an indication of the Government's attitude' and, as a consequence, the company 'would take steps to close the mine'. ${ }^{8}$ The loan funds sought were for capital equipment, including trucks to maintain continuity of production. The government's consideration of this request was influenced by the possibility that Mount Lyell may close and, if forced into liquidation, the company may not be in a position to meet severance payments for workers. In addition, the potential impact on employment levels at Electrolytic Refining and Smelting's operations at Port Kembla was a consideration if this operation were not able to be supplied with copper concentrate from Mount Lyell. ${ }^{9}$ The first of a series of government financial

6 Extract from 'I.A.C. Inquiry re Copper Ores and Concentrates, Tuesday 6th September, 1977', official transcript of proceedings, pp. 632-636, RGCA, Box 746.

7 ibid., p. 636.

8 Cabinet Minute, Canberra, 15 August 1977, Decision No. 3624, National Archives of Australia, Tasmania (NAAT), A12909, 1584; Cabinet Minute, Canberra, 28 February 1978, Decision No. 4726, NAA, A12909, 1937.

9 Cabinet Minute, Canberra, 28 February 1978, Decision No. 4726, NAA, A12909, 1937. 
assistance measures were implemented with a $\$ 3.3$ million Tasmanian Government subsidy, although the government did not accede to an offer to purchase the Lake Margaret power station from the company.

From 1977, the revised operating plan for Mount Lyell-the Prince Lyell Extended Plan-was implemented. The main features of this new plan included an indefinite deferment of further capital works on the new Prince Lyell shaft complex, reduction of ore production from 2.2 million tons to 1.5 million tons per annum, the introduction of a five-day milling week, the centralisation of mining activities to the large lower-cost ore bodies, rationalisation of surface engineering facilities and the reduction of the workforce. The workforce was reduced by the retrenchment of 225 employees, taking the number of employees to 727 from over 1,000 12 months earlier. ${ }^{10}$ After achieving reductions in freight charges from Emu Bay Railway, the renegotiation of a three-year agreement with Mitsubishi generated savings of $\$ 6$ million. ${ }^{11}$ Plans were also made for the closure of the loss-making North-West Acid plant, with EZ Industries assuming Mount Lyell's interest in 1979. Despite these activities, Mount Lyell remained loss-making in 1977 and 1978. An increase in the copper price meant an operating profit of $\$ 795,000$ was recorded in the 1979 financial year and by 1980 the company's profit had increased to $\$ 9.5$ million, enabling the payment of a dividend for the first time since 1975. Repayment of the subsidies advanced by the Tasmanian Government also commenced in 1980. During the period, mining occurred from the Prince Lyell ore body, with mining advancing through a series of stopes from the 10 series to the 30 series, along with mining from other ore bodies, including Cape Horn and Crown Lyell. Larger underground trucks were purchased to reduce haulage costs as deeper mining occurred, while other initiatives were implemented, such as the replacement of the grinding mills with larger units. Exploration expenditure also increased.

By 1981, Mount Lyell was again adversely affected by low copper prices and unfavourable currency movements. Copeman had resigned as chairman and as an executive of CGFA in 1981. His replacement as chairman of Mount Lyell was LW Skelton, an executive director of CGFA, who observed in August 1981 that there was 'little opportunity for effecting further economies or increasing production to offset escalating

10 Industries Assistance Commission, 'Interim Report, Copper Ores and Concentrates', p. 20.

11 The Mount Lyell Mining and Railway Company Limited, 'Minutes of Meeting of Directors', 23 November 1978, p. 4, NAAT, NS 3924, Items 253-261. 
costs' and that in the absence of a material improvement in copper prices the financial outlook for Mount Lyell was again parlous. ${ }^{12}$ Furthermore, adoption of the earlier Prince Lyell Plan had meant a predominant reliance on a single source of ore for milling. Varying grades of mineralisation obtained from the Prince Lyell ore bodies meant there were impediments to achieving an appropriate quality and mix of ore feed grade to the milling plant. In effect, Mount Lyell was entering yet another period of challenging operating and financial conditions whereby options for the mine's continuation or closure again came under consideration.

\section{Mount Goldsworthy divestment}

An internal company study in March 1976 led to a decision to divest CGFA's position in iron ore. The study identified depletion of the iron ore reserves in the northern areas of the Mount Goldsworthy tenements. In turn, it was recognised that the long-term future of the joint venture would be dependent on the development of the reserves in the southern tenements, especially Mining Area C. At a board meeting in January 1976 that considered how CGFA could fund its commitment to Mining Area C, Donald McCall, the London chairman and managing director, stated that the 'whole iron ore position regarding the C.G.F.A. Group needed immediate and careful review' ${ }^{13}$ The principal issue was the likely capital expenditure of at least $\$ 550$ million and how CGFA would fund its one-third share.

Bart Ryan, who had become managing director in July 1976, and who had earlier direct experience of the Mount Goldsworthy iron ore operation, believed the capital cost could increase to at least $\$ 900$ million. For him, it was whether this was an appropriate investment, with the 'problem of financing the investment ... not insurmountable but formidable'. ${ }^{14}$ In fact, based on a 1974 re-examination of the development of Shay Gap on then prevailing costs and prices, it was determined that 'at the present time development of Mining Area "C" does not appear to be a viable proposition'. ${ }^{15}$ At a time when the Australian group's investments were

12 The Mount Lyell Mining and Railway Company Limited, 'Minutes of Meeting of Directors', 27 August 1981, p. 2, NAAT, NS 3924/1/57, Items, 169-179.

13 Consolidated Gold Fields of Australia Limited, 'Minutes of Meeting of Directors', 28 January 1976, p. 9, RGCA, Box 12246, RGC 11588.

14 Consolidated Gold Fields Australia Limited, 'Minutes of Meeting of Directors', 26 May 1976, p. 9, RGCA, Box 12246, RGC 11588.

15 ibid. 
showing poor or variable returns, with the exception of Renison, and where further capital was in all likelihood required for a number of these investments, the issue with a large capital commitment to its iron ore operations was recorded at board level as follows:

Mr Ryan noted that the investment would not produce a return until the 1980's, yet it would have to be made at a time when we already have committed substantial investments which themselves would not show returns for some years, for example, Gunpowder, Mount Lyell, Western Titanium and Bellambi. Mr Ryan therefore posed the question as to whether it was sensible for Consolidated Gold Fields Australia even to contemplate a massive investment in MAC and expressed the view that there was a strong case for full divestment if a buyer could be found at a sensible price. ${ }^{16}$

A concern expressed was that if CGFA was not able to follow through on the development of Mining Area C, the current operations at Mount Goldsworthy, Shay Gap and Sunrise Hill could be adversely affected before their reserves were exhausted. The likelihood was that part of the workforce would leave these operations before their completion to secure alternative employment, with a difficulty in replacing these workers.

In Sid Segal's view, the London parent was better placed to raise the finance required for the potential development of Mining Area C. He believed that the interest burden of an investment in Mining Area C for CGFA would be 'huge' and in the context of a number of projects and a high level of debt, 'a divestment deal which gives us cash would best serve our interests'. ${ }^{17}$ It was recognised that one of the other joint partners, Cyprus Mines Corporation, was financially stretched and had no other Australian interests. While Utah Construction \& Mining Co. was in a stronger financial position, its interest in the Bowen Basin coal deposits was expected to consume its attention and financial resources. Ryan indicated his intention to make 'some delicate preliminary soundings' to Utah executives to see whether they may be interested in increasing their stake in Mining Area C. ${ }^{18}$ Approaches were also made in 1975 to Melbourne-based mining companies, while CGFA contemplated offering participation of up to 10 per cent to Japanese steelmakers. An agreement was instead reached with Mount Isa Mines in August 1976 for it to acquire a 20 per cent interest in the Mount Goldsworthy joint venture.

16 ibid.

17 ibid., p. 11.

18 ibid., p. 10 . 


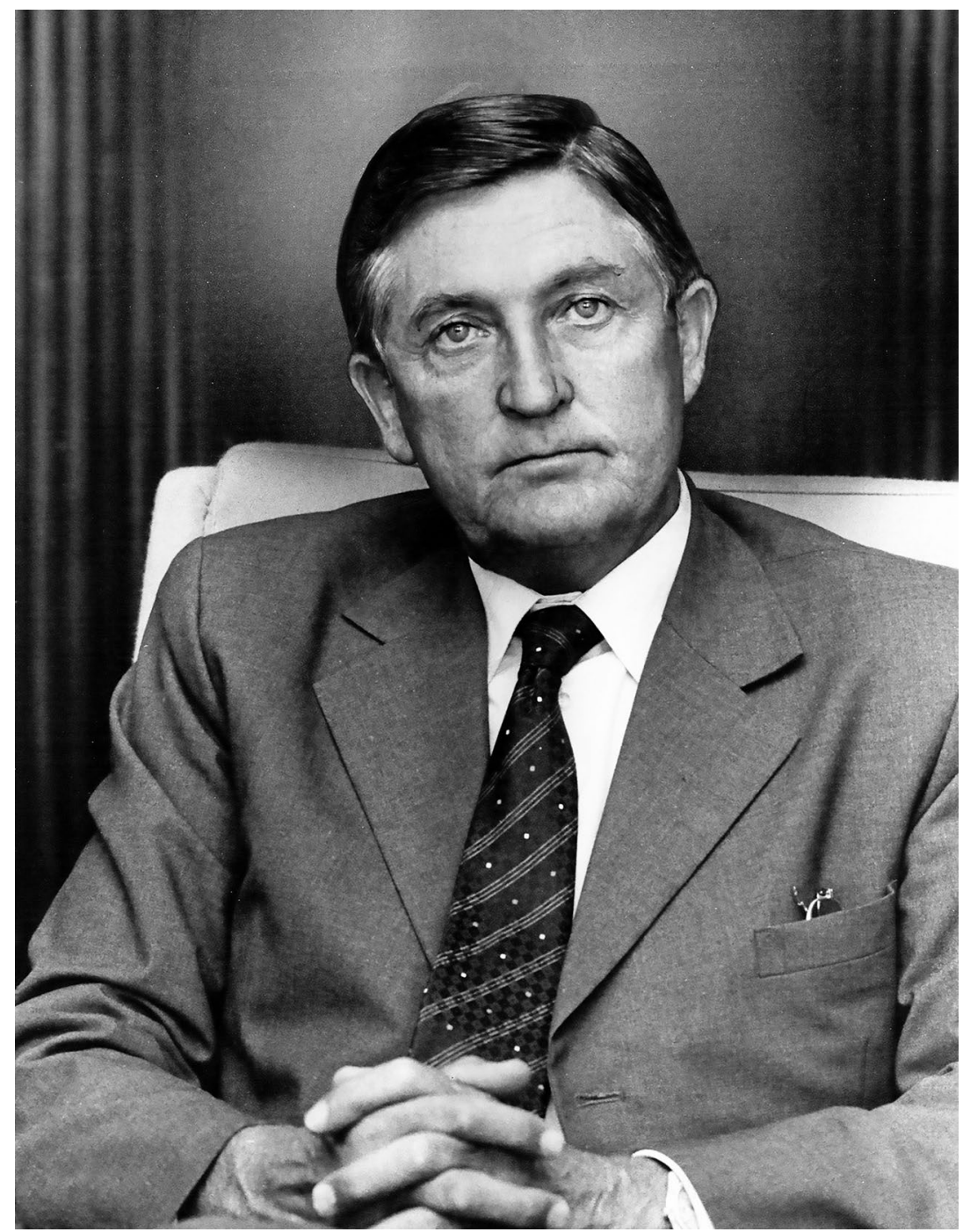

Figure 40. Bart Ryan, managing director of Consolidated Gold Fields Australia, 1976-1980.

Source: Alan Purcell, Sydney Morning Herald, Nine Publishing. 


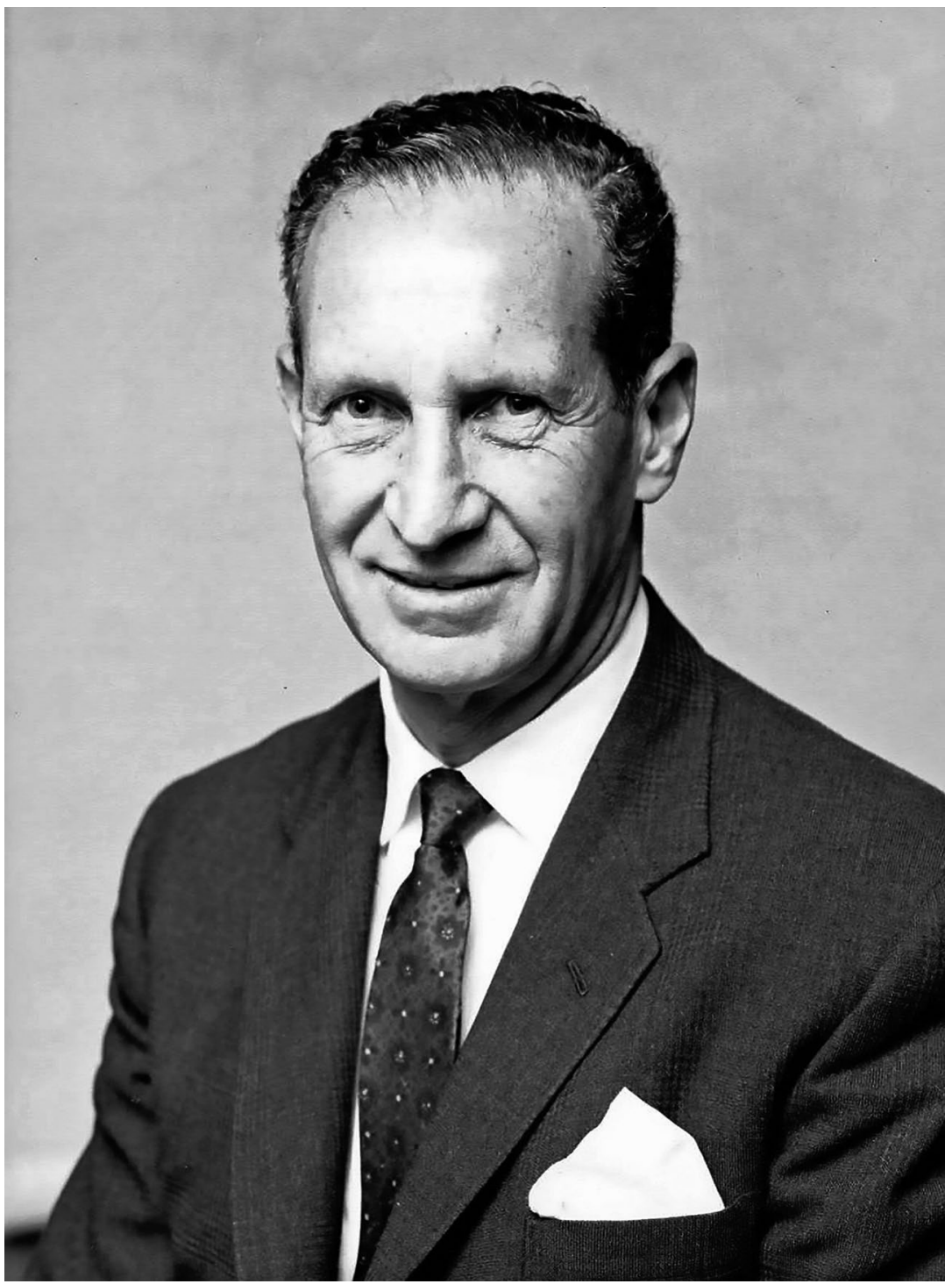

Figure 41. Sidney Segal, executive and subsequently chairman of Consolidated Gold Fields Australia from 1976 to 1980, then deputy chairman and director until 1982.

Source: Image courtesy of Jillian Segal. 
Given that the Mount Goldsworthy joint venture had not been successful in negotiating a contract with the Japanese steel mills for Mining Area C iron ore tonnage, the board came to the decision that involvement in the Mining Area $\mathrm{C}$ development 'was not an appropriate investment for Consolidated Gold Fields Australia'. ${ }^{19}$ Segal, as the chairman, conveyed a longer-term view of the company's iron ore interest:

Whilst the present picture for iron ore was bleak with low iron ore prices and an appalling cost structure, the Chairman felt it must be recognised that the Japanese would remain dependent upon Australia indefinitely into the future for a very significant part of their iron ore requirement. He noted that their offtake from Australia was currently in excess of $50 \%$ of their requirements and that the Japanese will always need ore. It had always been the Chairman's view that once we got to the point of obtaining a contract for MAC it would be possible to restructure our interests by disposing of part of it to the Australian public ... [and] this is still the way to proceed. ${ }^{20}$

Ryan, however, was of the view that the iron ore industry in Western Australia had 'descended into industrial anarchy'. Furthermore, in his view Hamersley Iron Ore had invested 'huge sums ... and the return on investment was extremely poor'. ${ }^{21} \mathrm{He}$ warned that the route proposed by the chairman was a 'possible duplication of the Robe River experience' and was firmly of the view that iron ore was 'unlikely to be a good investment for a very long time'. ${ }^{22}$ Ryan recommended complete divestiture. This was the board's decision, with the London parent, Consolidated Gold Fields, indicating it would consider acquiring some part of the interest on divestiture. The sale of a 30 per cent interest of CGFA's one-third holding in Mount Goldsworthy to Mount Isa Mines was agreed and in May 1977 an extraordinary general meeting of shareholders was held to seek approval for the sale of the residual 70 per cent interest to a Consolidated Gold Fields subsidiary, CGF Iron Pty Ltd.

19 Consolidated Gold Fields Australia Limited, 'Minutes of Meeting of Directors', 25 August 1976,

p. 4, RGCA, Box 12248, RGC 11575.

20 ibid., p. 5.

21 ibid., pp. 5-6.

22 ibid., p. 6. 
Segal addressed shareholders to explain the reason for the sale, conceding:

We have become disenchanted with iron ore. We lost money last year and we are losing money this year ... Even if we had a different view, we saw ourselves as unable to find our share of the funds necessary to open up Mining Area 'C' ... Combined, we would have been exposed to too great a risk and our whole enterprise put at risk if the future iron ore operation failed to perform, in that prices were too low, costs were too high and/or demand proved to be inadequate, and natural disasters befell us. ${ }^{23}$

The payment from Consolidated Gold Fields for its interest was in two parts. An amount of $\$ 12.47$ million was paid on completion of the transaction to sell CGFA's interest in the Mount Goldsworthy joint venture. The second component was a payment of $\$ 19.8$ million that would be made when and if production commenced from Mining Area C.

CGFA's involvement in iron ore initially formed one of the major bases of its earnings and cash flow. The divestment was a seminal strategic decision. It was the most profound change in the CGFA portfolio up until that time. It occurred in the context of considerable disquiet by the London parent about the overall financial performance and management of its Australian subsidiary that, in turn, contributed to Massy-Greene's replacement as managing director and his retirement as chairman. Although inconceivable to realise at the time in light of business conditions, but as alluded to by Segal, it may also rank as one of the most profound inhibitions on the longevity of the Gold Fields group in Australia. Nonetheless, part of the Goldsworthy interest was retained by the London parent. There was a later attempt to reacquire this interest by Renison Goldfields Consolidated. However, by this stage, Consolidated Gold Fields had come under takeover threat first from Minorco and then by Hanson. The parent's interest in the Goldsworthy joint venture that, under other circumstances, was likely to be returned to the Australian entity was sold, not to Renison Goldfields Consolidated, but to BHP.

23 'Chairman's Speech 1976 Extraordinary Shareholder Meeting on 6th May 1977 for Sale of $70 \%$ of its Interest in Mount Goldsworthy JV to CGF Iron Pty Ltd, a Wholly Owned Subsidiary of Consolidated Gold Fields', p. 2, RGCA, Box 12246, RGC 11584. 


\section{Portfolio restructure}

The sale of CGFA's interest in the Goldsworthy joint venture was associated with a review of the wider portfolio. Bellambi Coal remained on the market, and eventually sold in 1979, after Copeman advised that he was no longer able to recommend further capital expenditure for the operation. Production from the Gunpowder copper project was suspended in September 1977, with CGFA's investment folded into the group company, Circular Quay Holdings. Commonwealth Mining Investments (CMI) was retained in the portfolio and while contributing to CGFA's overall performance, it presented its own challenges. Apart from the board's view that CMI's turnover of some of its investments four times a year was incompatible with CGFA's position as a public company, the other issue was that a decision to dispose of a particular share investment might be 'inimical to the interests of the Group as a whole' and if such shares were offered to CGFA, the issue of 'insider trading' may be encountered. ${ }^{24}$ The CGFA board initially considered taking over CMI, although this idea was abandoned. Instead, the sale of CGFA's shareholding to National Mutual occurred in 1977. The CMI board minutes of 22 March 1978 recorded:

The Chairman stated that before formally closing the Meeting he felt it was appropriate to express his deep personal regret that the long and close relationship between CGFA and CMI had come to an end. During the seventeen years which had elapsed since CMI became a member of the Gold Fields Group, the skilful management exercised by CGFA had enabled the Company to achieve a considerable measure of success during a period of rapidly changing and sometimes extremely difficult market conditions. ${ }^{25}$

Smaller investments in agricultural activities through Colinas were a continuing disappointment and efforts were made to sell this business. The interest in North-West Acid was surrendered in 1979. CGFA had maintained an investment in Pancontinental Mining since the discovery of the Jabiluka uranium deposit, with close to a 15 per cent shareholding and a seat on the Pancontinental board, while also supporting the company's

24 Consolidated Gold Fields Australia Limited, 'Minutes of Meeting of Directors', 24 August 1977, p. 13, RGCA, Box 12246, RGC 11590.

25 Commonwealth Mining Investments (Australia) Limited, 'Minutes of Board Meeting', 22 March 1978, University of Melbourne Archives (UMA), Commonwealth Mining Investment (Australia) Limited Board Minute Books, 1955-1979, 2012.0202. 
exploration activities. In 1976, as part of the company's rationalisation of assets in the context of straitened financial circumstances, its shareholding in Pancontinental was sold, generating \$3.75 million in cash.

\section{Questioning the involvement in mineral sands}

Preceding a broader strategic consideration of the role of mineral sands in the CGFA portfolio, the merger of Associated Minerals Consolidated (AMC) and Western Titanium was seen as the first, logical step in rationalising the group's involvement in the mineral sands sector, quite apart from the expected greater efficiencies to be achieved by integrating the two subsidiaries. The merger proceeded in the context of AMC's high level of debt, a dramatic decline in rutile prices in 1972, the collapse of the zircon price-as demand for zircon as a refractory material in Japanese steel plants reduced - and a serious shortfall in production from the recently commissioned Eneabba operation in Western Australia. Furthermore, the two companies faced a potential competitive threat associated with the entry of additional sources of supply from South Africa and Sierra Leone. Overlaying these issues was AMC's declining reserve base as a consequence of the regulatory restrictions on its Australian eastcoast operations.

The amalgamation of the two companies reflected deeper concerns regarding the value of retaining mineral sands in the portfolio, given the high level of capital being committed to the industry with inadequate returns generated. The view of one CGFA director was that 'AMC needed Western [Titanium's] reserves and likely future profitability'. ${ }^{26}$ As to Western Titanium's prospects, it was the view of another director that the company could founder in the next year or so unless the merger takes place, or CGFA were to pour in money ${ }^{27}$ A 1976 internal CGFA document formalised the plan for AMC's takeover of Western Titanium. The merger was seen to be in the best long-term interests of both companies and as offering greater financial stability for Western Titanium, less risk from adverse mineral sands markets and benefits for AMC in terms of additional reserves and access to Western Titanium's 'strong position in ilmenite upgrading technology'. Other benefits included advantages in

26 Consolidated Gold Fields Australia Limited, 'Minutes of Meeting of Directors', 13 December 1976, p. 2, RGCA, Box 12248, RGC 11576.

27 ibid. 
marketing, the enhanced potential 'of becoming the largest and lowest cost producer in the growing beneficiated ilmenite area through technological leadership and scale economies', as well as reducing the complexities and capital inefficiencies for CGFA in having two subsidiaries, which on occasions_as was the case with synthetic rutile-pursued competing business interests. ${ }^{28}$

With AMC's growth options severely truncated as a result of environmental opposition to sand mining along parts of the New South Wales coast, as well as Queensland, the use of this company's technical and marketing skills across the broader portfolio of mineral sands opportunities provided by Western Titanium was viewed as the basis for the next phase of the company's evolution. With this, increased interest from the investment community was expected, with an improved ability to raise equity capital. ${ }^{29}$ An announcement of the proposed merger was made in September 1976, with the merger ratified at an extraordinary general meeting in October $1976 .{ }^{30}$

After the merger, mineral sands market conditions deteriorated. In 1977 circumstances were parlous, with the industry experiencing a period of uncontrolled competition, such that Copeman observed:

Mr. Mortimer would probably see similarities in the current position with that which prevailed fifteen or sixteen years ago when CGF had commenced investing in this country in that again there was destructive competition and a need to restore order. ${ }^{31}$

In 1977, the company's annual report noted the 'critical oversupply position', particularly for zircon, and an outlook that is 'not encouraging' without some form of industry 'rationalisation'. ${ }^{32}$ Zircon prices dropped from close to US\$200 per tonne in 1974 and 1975 to US $\$ 80$ per tonne between 1978 and 1980, before a partial improvement to above US $\$ 100$ per tonne in the early 1980s. Underpinned by contracts, the rutile price showed less volatility, although prices still declined in 1978.

\footnotetext{
28 'Summary Proposal for the Merger of Associated Minerals Consolidated Limited and Western Titanium Limited', 15 July 1976, RGCA, Box 12303, RGC 25508.

29 ibid.

30 Consolidated Gold Fields Australia exchanged 4,466,343 direct shares in Western Titanium for 3,509,269 shares in AMC - a ratio of 5.5 AMC shares for every 7 Western Titanium shares.

31 Consolidated Gold Fields Australia Limited, 'Minutes of Meeting of Directors', 26 January 1977, p. 5, RGCA, Box 12248, RGC 11575.

32 Consolidated Gold Fields Australia Limited, Eleventh Annual Report, 1977 and Notice of Meeting, p. 6.
} 
Market conditions were described by the company as 'one of destructive competition between Australian producers'. It was noted that 'until the situation improves, the company and the whole industry face a period of uncertainty in an over-supplied world market'. ${ }^{33}$

In 1978, the first full year after the merger, AMC recorded a loss of $\$ 4.9$ million. The following year a barely break-even result was achieved. No final dividend was paid in 1977 and dividend payments were not made in the following two years. Segal conveyed the 'stark evidence of the depths of the depression in which the mineral sands industry has languished ... [with] conditions in our industry ... undoubtedly the worst in its history. ${ }^{34}$

Despite the merger of AMC and Western Titanium, the composition of the portfolio and, in particular, the attractiveness of continuing to invest in mineral sands remained under board scrutiny. Apart from market conditions, the mineral sands business encountered multiple challenges. Extensive problems were experienced in the commissioning of the Eneabba deposit in Western Australia. A CGFA report in January 1977 noted the 'performance at Eneabba is of serious concern. The expected upturn in production and quality of product has not been achieved'. ${ }^{35}$ A range of issues were identified, including a limitation on plant utilisation levels and throughput, a shortage of clean water, a shortage of separation capacity and the failure to consistently produce on-grade product. A major issue was the quality of the ore body being mined, with regions of 'rubbly laterite' and occasional 'massive lumps' of clay-bound material that caused damage to and blockages of the handling system. ${ }^{36}$ Given the contraction of AMC's operations on the east coast and the maturation of Western Titanium's reserves near Capel in Western Australia, Eneabba was a central component of the company's production base. It was viewed as a prime source of rutile and zircon, as well as essential in ensuring the availability of ilmenite for synthetic rutile production.

AMC was confronted with a number of critical decisions, based on its operating experience at Eneabba, which were viewed as affecting both the short-term and long-term prospects of the company. After four years of mining, the high-quality ore on the eastern side of the northern leases

33 Associated Minerals Consolidated Limited, Annual Report and Notice of Meeting 1977, p. 2.

34 Associated Minerals Consolidated Limited, 'Chairman's Address Annual General Meeting,

29 September 1978'.

35 'Western Titanium-Situation Report 17 January 1977', RGCA, Box 748S.

36 ibid. 
had been largely depleted. In 1978, rutile production was 35,000 tonnes. Without remedial action, production was likely to decline to 14,000 tonnes per year in three to four years. The short duration of the Eneabba mine plan created a sense of urgency for a new mining strategy to be implemented. A plan to expand rutile production was developed although the planned higher production would, at best, only compensate for the reduction from the company's east-coast operations.

Furthermore, the advent of a new competitive force, Richards Bay Minerals in South Africa, and an industry structure in Australia in which, in the words of the managing director, 'the players were seeking to cut each other's throats', created an imperative for change in the Australian industry, including some form of rationalisation. ${ }^{37}$ Various means to achieve a more efficient structure in the overall mineral sands industry in Australia were considered, including encouraging another major minerals company to build a position in the industry, with CGFA prepared to assist this outcome, if required, by selling its interest in AMC. CGFA approached CRA (Conzinc Riotinto Australia), which had interests in mineral sands in Australia, and Union Corporation, an equity participant in Richards Bay Minerals. The intention was to allow them to acquire AMC or establish a position in the new Eneabba province to facilitate more cooperative marketing arrangements.

The 'deep depression' in the industry, in the directors' view, required a rationalisation of the number of industry participants. The board was initially encouraged by CRA's expected re-entry into mineral sands by the company pursuing arrangements with Allied Eneabba and engaging in discussions with Jennings Industries, the two other mining participants at Eneabba. It was believed this might facilitate a rationalisation of the then uncoordinated development of the Eneabba deposits by three parties. Ryan held discussions with CRA, conveying the benefits of a more consolidated structure of marketing arrangements from its involvement in the industry. ${ }^{38} \mathrm{He}$ indicated that CGFA 'would not oppose CRA's deals with Allied and A. V. Jennings, nor would it resist CRA's entry to the East

37 Consolidated Gold Fields Australia Limited, 'Minutes of Meeting of Directors', 27 July 1977, p. 8, RGCA, Box 12246, RGC 11590.

38 Consolidated Gold Fields Australia Limited, 'Minutes of Meeting of Directors', 28 April 1977, p. 9, RGCA, Box 12248, RGC 11575. 
Coast industry'. ${ }^{39}$ AMC was itself interested in acquiring Consolidated Rutile Limited on North Stradbroke Island. In the view of the CGFA board:

If all the proposed deals were to come off, the nett effect would be that CRA and AMC would together control $80 \%$ of Australian rutile and zircon production ... the hope existed that the South Africans would be prepared to join in an orderly marketing program. ${ }^{40}$

The financial context of CGFA's support for its mineral sands business interests and the corresponding need for a more orderly marketing environment were recorded in board minutes in August 1977:

Mr Landrigan [an executive director] emphasized the degree to which C.G.F.A. was already backing its minerals sands producers and the extent to which this assistance is going to have to increase. It was envisaged by the end of December, if C.G.F.A. continued to provide support, its total exposure could be as high as $\$ 35$ million. ${ }^{41}$

CGFA began buying rutile from AMC to store, allowing the company to buy it back during more favourable market conditions. In 1978, Kerr-McGee, a pigment producer, was offered 55,000 tonnes of rutile and an option to acquire a further 27,000 tonnes. It was offered to KerrMcGee at a price of $\$ 150$ per tonne, in conformity with AMC's 'fire sale' strategy, whereby no profit was achieved but the proceeds contributed to improving the cash position of AMC..$^{42}$ At the same time, zircon was 'grossly oversupplied'. ${ }^{43}$ Segal held discussions regarding rationalisation of the zircon market, although proposed marketing initiatives with another Eneabba producer, Allied Minerals, were not progressed due to concerns by DuPont, its partner, relating to United States antitrust considerations. It was likely that the depressed market conditions for zircon would be

39 Consolidated Gold Fields Australia Limited, 'Minutes of Meeting of Directors', 25 May 1977, p. 7, RGCA, Box 12248, RGC 11575.

40 ibid.

41 Consolidated Gold Fields Australia Limited, 'Minutes of Meeting of Directors', 24 August 1977, p. 6, RGCA, Box 12246, RGC 11590. JP Landrigan had joined the company in 1963 and became financial controller before being appointed an executive director in August 1975.

42 Consolidated Gold Fields Australia Limited, 'Minutes of Meeting of Directors', 22 February 1978, p. 2, RGCA, Box 12246, RGC 11590.

43 ibid., p. 8. 
exacerbated by production commencing from Richards Bay Minerals. In this context, the chairman said 'it was imperative that A.M.C. take a cold, hard look at its future and plan accordingly'. ${ }^{44}$

In 1977, McKinsey \& Company was commissioned to undertake a review of the mineral sands industry and AMC's place within it. AMC's high level of debt remained a key issue. The desire was to have debt reduced sufficiently to allow the recommencement of dividend payments. It was recognised that AMC would likely require an injection of funds, which occurred in 1979 and 1980 through two separate rights issues. In September 1977, the initial findings of the McKinsey report were presented to the CGFA board of directors. Its main conclusion was that Eneabba's potential performance could be substantially better than had been expected and that rutile could be produced at a higher rate. The following month, the board considered the final McKinsey report. The options presented included continuing to operate the business with no major changes, instituting further substantial cutbacks in production with the intent to manage the company for cash, and expanding the business with a view to establishing market leadership and, as such, being in a position to influence mineral sands prices. This option was expected to optimise the benefits for AMC, with 'an essential first step' the acquisition of Allied Minerals. A final option of quitting the business and disposing of the mineral sands assets was also presented. ${ }^{45}$

The board determined that 'AMC be placed on a survival footing' and that merger discussions be initiated with Allied Minerals. Segal believed that a merger would be difficult to achieve and instead proposed an alternative approach that entailed a 'vigorous pursuit of [the] beneficiation route' through an arrangement with Tioxide, one of the major pigment customers. Discussions were held with Tioxide, designed to secure an offtake arrangement for the upgrading of ilmenite to produce synthetic rutile. ${ }^{46}$ Tioxide's London board determined in 1977 that its support for an additional beneficiation plant was not warranted in light of the global pigment situation. ${ }^{47}$

44 Consolidated Gold Fields Australia Limited, 'Minutes of Meeting of Directors', 27 July 1977, p. 8, RGCA, Box 12246, RGC 11590.

45 Consolidated Gold Fields Australia Limited, 'Minutes of Meeting of Directors', 26 October 1977, pp. 3-4, RGCA, Box 12246, RGC 11590.

46 ibid., p. 5.

47 Consolidated Gold Fields Australia Limited, 'Minutes of Meeting of Directors', 23 November 1977, RGCA, Box 12246, RGC 11590. 
In considering the arrangements for industry rationalisation, Ryan held discussions with several parties for a potential 'four-way merger' at Eneabba. Board minutes noted that:

It appeared the concept would be supported by DuPont, Allied Minerals, and the Western Australian Government, and to some extent by Union Corporation ... but [Union Corporation] was not prepared to see Consolidated Rutile itself merge its operations. It appeared, as a result of McKinsey's work, that unless Richards Bay were prepared to co-operate in market rationalisation the projected Eneabba merger would not correct the zircon market. ${ }^{48}$

McKinsey's option of expanding the business and acquiring Allied Minerals' Eneabba operations was viewed by the CGFA board as something that should be explored. Discussions with Allied Minerals and DuPont were held. It became apparent that 'DuPont's main interest lay in having a stable ilmenite source', rather than continuing as an equity holder in an Australian mineral sands operation. ${ }^{49}$ This was the basis for the eventual acquisition of Allied Eneabba as part of CGFA consolidating the production base at Eneabba.

Despite the support of most of the Australian directors, Rudolph Agnew, the Consolidated Gold Fields group chief executive officer and deputy chairman, expressed his opposition to the proposed acquisition:

Mr Agnew informed the Board that he could not recommend to C.G.F. that it support the proposal or participate therein ... [with] further major investment in the minerals sands industry ... intolerable..$^{50}$

The Australian directors accordingly determined not to pursue the acquisition. As such, this prime component of consolidation in what was becoming the key mineral sands production province in Australia was forestalled, if only temporarily.

48 Consolidated Gold Fields Australia Limited, 'Minutes of Meeting of Directors', 28 September 1977, p. 5, RGCA, Box 12246, RGC 11590.

49 Consolidated Gold Fields Australia Limited, 'Minutes of Meeting of Directors', 21 December 1977, p. 4, RGCA, Box 12246, RGC 11590.

50 Consolidated Gold Fields Australia Limited, 'Minutes of Special Meeting of Directors', 10 February 1978, p. 1, RGCA, Box 12246, RGC 11590. 
The disposal of AMC remained under consideration. The main factor forestalling a decision to sell was the expectation that a better price may be gained in the future, although the view in the first half of 1978 was that 'this did not appear particularly likely on our present view of the industry'. ${ }^{51}$ Ryan, a less-than-enthusiastic supporter of the mineral sands business, pointed out:
A.M.C. would not be profitable for two years at least and thereafter would provide only a minimal return. It was clear that the only way this picture could change would be for a dominant producer to take control of the industry and change the pricing structure and it had been agreed that this was not a position which CGFA should seek to obtain at this time..$^{52}$

By June 1978, the disposal of its mineral sands businesses appeared impracticable, with other alternatives then under consideration, including CGFA purchasing the minority interests of AMC or reducing its shareholding below 50 per cent and thereby decreasing its obligations in relation to loan guarantees. ${ }^{53}$ Whether DuPont would be a buyer of AMC was discussed by directors although rejected as unlikely given DuPont's approach to not typically holding positions in offshore operations due to the antitrust laws of the United States.

The situation, compounded by the likely market obstacles in executing plans to sell other assets in the portfolio to facilitate a potential joint venture with Utah to acquire Renison, led to the board's consideration 'to "batten down" and try to make the group work as it is' ${ }^{54} \mathrm{~A}$ degree of optimism had also entered the board's thinking on the mineral sands industry. In July 1978, the view was expressed that it appeared that AMC would no longer present a grave threat to CGFA'. 55 The Titanium Enterprises' mineral sands operation in Florida had also come to the company's attention, viewed as an opportunity for CGFA to effect a progressive consolidation of the mineral sands industry, in this case by the application of AMC's technology to 'transform' a United States

51 Consolidated Gold Fields Australia Limited, 'Minutes of Meeting of Directors', 22 March 1978, p. 11, RGCA, Box 12246, RGC 11590.

52 ibid., p. 10.

53 Consolidated Gold Fields Australia Limited, 'Minutes of Meeting of Directors', 28 June 1978, p. 2, RGCA, Box 12246, RGC 11592.

54 ibid., p. 4.

55 Consolidated Gold Fields Australia Limited, 'Minutes of Meeting of Directors', 26 July 1978, p. 4, RGCA, Box 12246, RGC 11592. 
operation. ${ }^{56}$ Segal observed optimistically 'that CGFA had come into the mineral sands industry when it was in gross disarray and this is again the situation in this country'. For him, 'the present time may thus be another good take-off point for growth'. ${ }^{57}$

In early 1979, the findings of another McKinsey study of AMC were received. It proposed a low-risk expansion strategy that would entail AMC taking a lead in the rationalisation of the Eneabba field. In the case of Allied Eneabba (formerly Allied Minerals), this was envisaged through a joint venture or marketing arrangement, with an outright acquisition not seen as appropriate given Allied Eneabba's level of debt. Discussions with Jennings were also proposed. The acquisition of Titanium Enterprises in the United States, which was in progress, was viewed by McKinsey as 'a useful but less attractive stratagem'. ${ }^{58}$

The projected profile of CGFA's mineral sands business by McKinsey was one of moderate growth, highlighting the need to reduce debt, which brought to the fore the need for a rights issue. Discussions with Allied Eneabba and DuPont began in early 1979 regarding a joint venture, while CGFA's view in relation to Jennings Industries was that, while it would like to have Jennings' leases as 'reserves for the future', it was thought it would 'not be prudent to make a bid for [Jennings'] fixed assets except, possibly, for the wharf facilities' ${ }^{59}$ Ryan realised that a deal to acquire Titanium Enterprises could provide the necessary rationale for AMC to approach shareholders with a rights issue.

At a special meeting of directors on 11 April 1979, the board resolved to support a rights issue, predominantly for the purpose of acquiring the Titanium Enterprise mineral sands operation in Florida, but also to allow the partial repayment of CGFA loans to AMC. A company report presented to the board in the same month on the optimisation of the Eneabba reserves provided encouragement for 'the aggregation of further reserves', with the proposal that CGFA acquire the Jennings leases on

56 Consolidated Gold Fields Australia Limited, 'Minutes of Meeting of Directors', 23 August 1978, p. 4, RGCA, Box 12246, RGC 11592. The prospect of the sale of AMC had not been completely abandoned.

57 Consolidated Gold Fields Australia Limited, 'Minutes of Meeting of Directors', 22 November 1978, p. 5, RGCA, Box 12246, RGC 11592.

58 Consolidated Gold Fields Australia Limited, 'Minutes of Meeting of Directors', 24 January 1979, p. 5, RGCA, Box 12246, RGC 11592.

59 Consolidated Gold Fields Australia Limited, 'Minutes of Meeting of Directors', 28 February 1979, p. 13, RGCA, Box 12246, RGC 11592. 
behalf of AMC and 'ware-house' them for future use. ${ }^{60}$ By this stage, Jennings had formed its own board subcommittee to progress the sale of its Eneabba operations. On 30 November 1979, Jennings Industries was acquired by CGFA.

Considerable efforts were expended to address the operational and market-related challenges of the main investments of the CGFA portfolio during the 1970s. These included a divestiture of some holdings, such as iron ore, and the attempted improvement in the financial prospects of others through cost reduction and production efficiency activities, in the case of Mount Lyell, or aggregation activities, in the case of mineral sands. While progress was made on all of these fronts, the fundamental consideration remained the appropriate structure of CGFA's business model. This matter was addressed in detail from the mid-1970s and would lead to the formation of a new corporate structure in 1981 .

60 Consolidated Gold Fields Australia Limited, 'Minutes of Meeting of Directors', 26 April 1979, p. 8, RGCA, Box 12272 . 
This text is taken from Consolidated Gold Fields in Australia: The Rise and Decline of a British Mining House, 1926-1998, by Robert Porter, published 2020 by ANU Press, The Australian National University,

Canberra, Australia.

doi.org/10.22459/CGFA.2020.12 